\title{
Learning to love again: 'Broken families', citizenship and the state promotion of coupledom
}

\author{
Eleanor Wilkinson \\ School of Geography, University of Leeds, Leeds LS2 9JT, United Kingdom
}

\section{A R T I C L E I N F O}

Article history:

Available online $\mathrm{xxxx}$

\section{Keywords:}

Broken families

Citizenship

Coupledom

Intimacy

Same-sex marriage

Sexuality

\begin{abstract}
A B S T R A C T
This article explores the ways in which coupledom is promoted through contemporary family policy in the UK. It does this in the context of dominant political discourses suggesting that broken relationships are a major political problem and the cause of almost all that is wrong with British society today. The paper performs an analysis of recent family policies, revealing narratives claiming that stable coupled relationships are the foundation of a strong nation. The reverse of this narrative, therefore, is that to not be in-or even worse, to not even aspire to be in-a coupled relationship is not just a personal failure, but a failure for the nation as a whole. The article therefore argues that the UK government encourages a particular type of intimate relationship, despite an increasing recognition of 'diverse' family forms. Building upon Rich's notion of compulsory heterosexuality, the article concludes that what we are witnessing in current British society is not compulsory heterosexuality, but compulsory coupledom.
\end{abstract}

(c) 2013 Elsevier Ltd. All rights reserved.

\section{Introduction}

Previous research has highlighted the importance of sexuality in defining the parameters of nationhood, noting that heterosexuality can be seen as 'foundational to constructions of the nation-state' (Nast, 1998: 191; Mayer, 2000). Existing studies have exemplified the ways in which the nuclear family and heterosexual conjugal coupledom have been invoked as the bedrock of post-war Britain by both centre-left and conservative right governments, providing the cornerstone of the welfare state as well as the 'enterprise culture' that gradually led to its erosion (Cooper and Herman, 1991; Smith, 1994, 2007). However, it has been widely argued that in recent decades British society has witnessed 'a certain disruption and destabilization of heterosexuality' (Richardson, 2000: 3), with citizenship now no longer necessarily always tied to heterosexuality in legal and political discourse (Stychin, 2006a). One important dimension of this is the ways in which lesbian and gay couples appear to have been incorporated into the 'charmed circle' not just of accepted sexual practices (Rubin, 1984), but also official imaginings of the British nation-state. However, in this article I ask whether the inclusion of same-sex relationships could be seen to be simultaneously opening up and narrowing down the charmed circle of 'appropriate' intimacies. I will go onto argue that despite the supposed increasing acceptance of sexual diversity, an exclusionary rhetoric of 'family values' still continues to circulate within policies that are seeking to create equality.

E-mail address: e.k.wilkinson@leeds.ac.uk
The article focuses upon changes to family policy since the New Labour government came to power in 1997. The period of government under New Labour was particularly important for lesbian and gay equality in Britain as there were a number of significant legislative reforms that saw lesbian and gay couples achieve almost full citizenship status. Family law, employment law, equality and diversity legislation all began to recognize lesbian and gay rights, with some of the most significant moves being the Civil Partnership Act of 2004, and the right for lesbian and gay partners to adopt from 2002 (Browne, 2011; Peel and Harding, 2008). Under New Labour, Britain witnessed a dramatic shift away from the previous Conservative (1979-1997) governments' privileging of heterosexuality. Moreover, further reform is taking place, with legislation over 'same-sex marriage' currently passing through parliament.

These significant moves towards full (sexual) citizenship have led some commentators to take a highly optimistic overview of the gains that have been won for lesbian and gay people (Weeks, 2007). ${ }^{1}$ Yet in this article I argue that caution is needed when it comes to celebrating these newfound rights and responsibilities. It is important that we take into account the cultural, economic, and political climate in which this new legal landscape has emerged. The state recognition of same-sex partnerships comes at a time when Britain is witnessing the increasing disintegration of the nuclear family, with rising divorce rates, an increase in lone-parents, and an unprecedented rise of 'non-traditional' families and varied

\footnotetext{
${ }^{1}$ Existing research has highlighted how the Civil Partnership Act will only benefit certain couples, as the legal recognition of civil partnerships may in fact be detrimental to those who receive state benefits (McDermott, 2011; Taylor, 2011).
} 
household structures (Duncan and Smith, 2003; Roseneil and Budgeon, 2004). In this context, the recognition of same-sex partnerships was seen by some policy makers as a way to actively promote the values of long-term coupledom.

In this article I explore what happens when the nation-state is, at one level, no longer attempting to privilege heterosexuality but, at the same time, continues to promote particular forms of intimacy and family life. I question whether a diverse range of intimate attachments are now genuinely included into the imagined British nation, and ask what space there is for relationships that exist outside of coupled sexual-love, such as friendships, multiple partners, or being single. I propose that the British nation may now best be thought of as founded upon mononormativity rather than solely heteronormativity. Here, mononormativity refers to the 'ideological force of couple culture' (Budgeon, 2008: 302), the presumed desirability of coupledom, and discrimination against those whose intimate lives do not fit this conventional dyadic form (see Adeniji, 2001; Barker and Langdridge, 2010; Pieper and Bauer, 2005; Wilkinson, 2012). Adrienne Rich (1980) introduced the notion of 'compulsory heterosexuality' to describe the ways in which heterosexuality is enforced through societal pressures and economic incentives; this article examines how these now help to maintain not just heteronormativity but also mononormativity. Consequently I argue that what we are witnessing in current British society is no longer compulsory heterosexuality, but compulsory coupledom.

The article thus proposes that the concept of sexual citizenship, which has been pivotal for much geographical work on sexual rights and equality (Bell and Binnie, 2000, 2006), needs to also be considered in relation to debates around intimate citizenship (Hubbard, this issue; Plummer, 2001, 2003; Roseneil, 2010). As Plummer (2001: 242) outlines, intimate citizenship can be seen as a 'broader' more 'inclusive concept', 'one that is less focussed on the sexual'. Plummer (2001: 238) argues that intimate citizenship enables us to group together 'a series of somewhat disparate concerns around personal life' such as 'single parenting', 'cohabitation', 'the value of living alone', 'voluntary childlessness'; and 'adult friendships'. Focussing upon intimate citizenship allows for the inclusion of a broader array of personal attachments that are not always directly related to sexuality, and helps challenge the ways in which sexual-love relationships are seen to take precedence over other forms of intimate attachment.

The first half of the article outlines some of the key shifts in family policy that have occurred in Britain since 1997, highlighting the move from the privileging of the married heterosexual nuclear family to the recognition of a broader range of diverse family formations. Data gathered for this article comes from an archive of material including government consultation documents, policy papers, and parliamentary debates. ${ }^{2}$ My analysis pays particular attention to the language used to talk about coupledom, and draws out the ways in which long-term coupledom is portrayed not just as a private good, but as having wider benefits for society, and the nation-state. ${ }^{3}$ It demonstrates how stable coupled relationships continued to be promoted as the foundation of a 'decent' and good society under New Labour. In the second half of the article I explore which subjects are excluded from these new imaginings of the British nation, and ask who exists on the margins of this supposedly inclusive new family policy. In this section I argue that citizenship is no longer

\footnotetext{
${ }^{2}$ A number of these policy documents affect England and Wales only, as the Scottish Parliament are currently developing their own family policy framework.

${ }^{3}$ I conducted a critical discourse analysis of a range political and media debates about coupledom in order to highlight the discursive construction of singleness as a 'problem'. I situate my analysis within a particular historical moment and seek to highlight the changing political context in which these policies have developed (see Denzin and Lincoln, 1998; Fairclough, 2000).
}

necessarily always founded upon a binary between heterosexual/ homosexual but between the coupled and the non-coupled. I conclude the article by offering some thoughts about why these 'new equalities landscapes' arose at this particular point in history and also consider the potential future directions these policies might take under the current Conservative-led coalition government. ${ }^{4}$

\section{The shifting contours of family policy in Britain}

When New Labour came to power in 1997 they claimed to offer a 'third way' between the socialist left-wing values of 'Old Labour' and the neoliberal and pro-market views of the Conservative party. However, a number of commentators have questioned just how 'new' New Labour policies were, and, as Powell (2000: 54) notes, New Labour's 'continuities with the Conservatives far outweigh those with Old Labour'. Powell (2000: 53) therefore claims that New Labour policy might be best summarized by the acronym of PAP: 'pragmatism and populism', given the ways their policies marked a moved towards the centre ground of politics, and often pandered to public opinion. This populist and pragmatic approach can clearly be seen when we examine New Labour family policy at the beginning of their time as government, as these initial documents about the family often displayed strong continuities with preceding Conservative family policies and programmes (Lister, 2001).

Such continuities are perhaps surprising given the Conservative government had introduced a 'back to basics' campaign during the 1990s which was strongly supportive of the traditional nuclear family and the institution of marriage (e.g. the Family Law Act, 1996). Alongside this was the vilification of family breakdown, and a moralistic disapproval of family forms deviating from the heterosexual nuclear family (see Edwards and Duncan, 1997, for an overview of the Conservative party's demonisation of lone motherhood). Initial New Labour policy documents proclaimed marriage as the superior family form which needed to be strengthened, despite the fact that the New Labour government were attempting to present itself as less morally prescriptive than its conservative forebears, and more tolerant of diverse family forms (Home Office, 1998; see Barlow and Duncan, 2000b for an overview). For example, at the start of New Labour's time in office, they published the first governmental consultation document written specifically on the family - Supporting Families (1998), Chapter Four of this was entitled 'Strengthening Marriage'. This part of the consultation claimed that there was a need 'to strengthen marriage to help more marriages succeed' (Home Office, 1998: 30), and argued that:

Family life is the foundation on which our communities, our society and our country are built. Families are central to this Government's vision of a modern and decent country. [...] Families are the heart of our society (Home Office, 1998: 4).

In this document marriage was seen as the foundation of family life, and was portrayed not just for the benefit of individuals and their children, but as something with wider benefits for society. Long-term conjugal coupledom was depicted as essential to community and the future of the nation, thus echoing Berlant and Warner's description of heteronormativity, where they highlight the ways in which:

[C]ommunity is imagined through scenes of intimacy, coupling, and kinship; a historical relation to futurity is restricted to generational narrative and reproduction [...] this privatized sexual

\footnotetext{
${ }^{4}$ The coalition government came to power in May 2010 when the minority rightwing conservative government secured the support of the Liberal Democrats (a party traditionally associated with the centre-ground of UK politics).
} 
culture bestows on its sexual practices a tacit sense of rightness and normalcy. This sense of rightness - embedded in things and not just in sex - is what we call heteronormativity (1998: 554)

Supporting Families was described by Barlow and Duncan (2000b): 129 as a clear attempt at social engineering, promoting certain 'desirable family forms' over other 'less-favoured family practices'. Some of the responses to the consultation (Home Office, 1999) therefore criticized the 'Strengthening Marriage' Chapter for its outdated focus upon heterosexual marriage, and its failure to recognise the diverse range of family formations that exist in Britain, such as same-sex partnerships.

Consequently, subsequent New Labour policy signaled a gradual acceptance of family forms beyond the heterosexual nuclear family, with one of the most significant moves being the introduction of Civil Partnerships in 2004. This recognition of same-sex partnerships was, in part, a result of campaigns for lesbian and gay equality, including pressure from within the Labour party and Civil Service. However, it was also a move that enjoyed popular support, with $83 \%$ of respondents to a government consultation stating that they supported Civil Partnership (Women and Equality Unit, 2003). Accordingly, the government shifted its focus away from promoting just heterosexual marriage, towards the recognition of a diverse range of family formations, signaling a move from 'the family' to 'families'.

During New Labour's time in government there was hence a significant change in family policy, with official pronouncements beginning to acknowledge that the traditional family unit was changing and that families need not always based around the heterosexual dyad. This shift can be seen in the titles of their 1998 policy document Supporting Families, to their 2010 Green Paper, Support for All. Another example of this transition can be seen in the Families in Britain Evidence Paper (DCSF, 2008: 7), which stated that 'families come in all shapes and sizes' and 'there is no such thing as a typical family in 21st Century Britain'. The government now claimed that 'a modern and effective family policy must also be based on the understanding that family means more than just parents and their children' (DCSF, 2010a: 21). Yet, it is questionable whether the New Labour government ever fully grasped the range of family formations that existed in Britain, as throughout these policy documents often the only examples given provide a limited range of 'diverse family formations', and 'family' was still often seen to amount to little more than 'parents, grandparents and carers' (DCSF, 2010a: 1).

So although New Labour family policy seemed to turn its focus away from heterosexual marriage to espouse a wider range of committed and loving relationships, these relationships were still often limited to long term coupledom or biological familial forms of kinship. It was clear that the government was still trying to uphold the 'right' kind of family and the right kind of couple. Long-term coupledom was still often portrayed as more desirable than other forms of relationship (see DCSF, 2008; LCD, 2002). Policy documents still continued to promote the importance of 'strong and stable relationships' and 'committed couples', with the government claiming that ' $[\mathrm{w}] \mathrm{arm}$, loving and stable relationships matter more for our happiness and wellbeing than the legal form of a relationship' (DCSF, 2008: 4). This document goes onto outline how it was no longer the actual legal contract of marriage that was seen as important, but the values of love, commitment and stability between parents. Government policy was now focusing on the importance of long-term coupled relationships, regardless of sexual orientation, and regardless of legal contract. However, although this definition of 'warm, loving and stable relationships' allowed non-married (but committed) couples to be included into these idealized notions of 'the family'; there was no mention of loving stable relationships between multiple partners or between friends; notions of 'love' and 'commitment' were still predominantly tied to the couple form. Underpinning New Labour's mononormative family policy was the assumption that long-term coupled relationships provided the most stable environment in which to bring up children (DCSF, 2008; Cabinet Office, 2007). Thus as Richardson and Turner (2001: 337) highlight, 'modern citizenship regards parenthood in 'normal' families, rather than heterosexuality as such, as the defining characteristic of the 'average' citizen and as the basis of social entitlement'. Those who exist outside of these traditional familial structures (e.g., those who raise children in alternative ways, the un-coupled, or the childless) are marginalized within these representations of the ideal household. Under New Labour there was still a strongly couple-centric understanding of 'the family', which excluded the contributions that could be offered by friends, relations or others who were not sexual partners.

Furthermore, despite this supposed recognition of diverse family formations, New Labour policies continued to uphold the idea that long-term coupledom is beneficial not just for family members and children, but for communities and for the nation. For example, the Lord Chancellor's Advisory Group on Marriage and Relationship Support stated that 'the adult couple [...] is the cornerstone of the family. Strong and stable relationships benefit all in society' (LCD, 2002: 33). Thus the policy shift away from marriage did not alter the ways in which the heteronormative narrative works; 'community' was still 'imagined through scenes of intimacy, coupling, and kinship' and futurity is reductively 'restricted to generational narrative and reproduction' (Berlant and Warner, 1998: 554). This pro-couple rhetoric bears close resemblance to some of the arguments used by Christian right groups when attempting to preserve heterosexual marriage from the 'threat' of same-sex marriage. In these narratives the married heterosexual couple provides the bedrock of community and national values, with homosexuality depicted as threat to Western civilization (Jakobsen, 2002; Cobb, 2006). The expansion of this heteronormative rhetoric to include non-married couples, and lesbian and gay couples under New Labour hence did little to challenge or denaturalize the reductive and exclusionary assumption that strong couples are the foundation of not just strong families, but also a strong nation. This underlines that the mononormative familial nation is not a natural phenomenon with complex discursive strategies and legal structures working to maintain its privileged status (Phillips, 2009).

Despite the introduction of the Civil Partnership Act it appears that the couple-centric familial nation remained unchallenged, and the basic premise upon which citizenship is granted was not brought into question. The parliamentary debates around Civil Partnership often presented a homonormative image of monogamous, committed, responsible lesbian and gay citizens, where same-sex couples are depicted as equally loving, and equally as beneficial to the wider community and the nation (see Duggan, 2002 for further discussion about homonormativity). Lesbian and gay partnerships have been incorporated into an existing heteronormative framework that values coupled-love, commitment and longevity. Anna Marie Smith (1994: 204), in her discussion about the figure of the 'good homosexual', suggests certain lesbian and gay subjects 'can be added to the social order without any fundamental transformation'. Yet the Civil Partnership Act is about more than simply just inclusion into the existing order for, as Bell and Binnie (2000: 58) highlight, the legal recognition of same-sex partnerships 'could have the function of reaffirming marriage as an institution'. I am interested in thinking about how the Civil Partnership Act can be understood as sending out a wider message about which forms of intimate relationships have value, and which do not. For example, when introducing the Civil Partnership Bill to the House of Commons, Labour MP Jacqui Smith claimed that 'the Bill sends a clear message about the importance of stable and 
committed same-sex relationships' and 'makes an important statement about this country's support for stable, long-term committed relationships' (HC, Hansard, 12/10/04: column 174 and 175). Longterm relationships were understood to be in decline in Britain, and therefore committed lesbian and gay couples were seen as being able to send out a timely reminder to their failing heterosexual counterparts. Conservative MP Alan Duncan put forward the case that civil partnership will be 'a way of protecting the family in changed times, not of damaging it' (HC, Hansard, 12/10/04: column 187), claiming that:

...the argument that they [same-sex couples] will damage the institution of marriage still does not stack up. If we preach that the values inherent in marriage - love, mutual commitment and responsibility - strengthen and enrich society, how can we claim that the replication of such values for gay couples will cause damage? Imitation is, after all, the sincerest form of flattery... [it] makes even more sense now to approve civil partnerships. (HC, Hansard, 12/10/04: column 188)

The political debates about the introduction of Civil Partnership were not solely framed as matters of gay and lesbian equality, but were also presented as part of a wider aim of strengthening the importance of long-term coupled relationships. For example, Conservative MP Robert Key claimed that the Bill will enhance the institution of marriage by increasing public approval for stable, committed, loving interdependent relationships in society' (HC, Hansard, 2004: Column 207). For certain MPs, it seems that the debate around Civil Partnerships gave them the opportunity to underline the importance of committed conjugal coupledom (see Stychin, 2006a, for a more in-depth analysis of these parliamentary debates $)^{5}$

\section{Lessons in Love? 'Broken families' and 'broken Britain'}

So far this article has explored some of the ways in which lesbian and gay couples became incorporated into dominant policy ideals of 'family'. These inclusions to citizenship have had a material effect not just on the political identities of the group who are newly included (Smith, 1994) $)^{6}$ but also on those who are excluded. Therefore it is important to continue to question who may still be excluded from these current models of mononormative citizenship. In order to think this through, I turn to Doreen Massey's discussion of the ways in which care and responsibility are still so often associated with proximity. Massey states that:

[...] certainly in Western societies, there is a hegemonic geography of care and responsibility which takes the form of a nested set of Russian dolls. First there is 'home', then perhaps place or locality, then nation, and so on. There is a kind of accepted understanding that we care first for, and have our first responsibilities towards, those nearest in (Massey, 2004: 8-9).

However, governmental rhetoric about coupledom implies that if you care for those 'nearest in' then you are also somehow caring for society and the nation; that there is a link between having a good, normative coupled life and being a good citizen. In these narratives people's intimate lives are not just private, but directly link to a wider societal good, the links between the intimate and the

\footnotetext{
5 The Civil Partnership Act could be read as a straightforward mononormative reinforcement of the couple form. However, such a reading perhaps runs the risk of inadvertently upholding the power of mononormativity. It is important to note that these parliamentary debates and policy documents simultaneously highlight the fragility of long-term coupledom and its diminution within contemporary British society.

${ }^{6}$ In this article I do not explore the lived experience of Civil Partnership, or how this notion of the 'good responsible gay citizen' may be challenged and subverted in everyday life (see Smart, 2007; Weeks et al., 2001).
}

nation in these policy discourses are often very overt. By being in a stable couple you are 'doing your bit' for the nation, and working towards the common good (see LCD, 2002). Loyalty to your partner becomes synonymous with loyalty to the nation. Consequently these positive narratives about the wider good of coupledom cannot help but exclude and further marginalize those who are not part of a coupled relationship. If strong families and couples create a strong nation then the reverse of this narrative also applies. The breakdown of couples, and the 'collapse' of the family is often portrayed as inextricably connected to the disintegration of the nation (see Barlow and Duncan, 2000a). To not be in-or even worse, to not even aspire to be in-a long-term coupled relationship can be depicted not just as a personal failure, but as a failure to society as a whole.

In Britain it therefore now appears that citizenship is no longer clearly delineated on the basis of a heterosexual/homosexual binary, but between couples and the uncoupled. ${ }^{7}$ Despite the supposed moves towards greater equality, the supreme logic of the child-bearing couple appears still to dominate British policy. The government speaks of the importance of long-term committed coupledom as the basis of 'family values', eschewing any discussion of single values. To be single is to seemingly be valueless; or worse, to be unattached is to be reckless, narcissistic, immature, and selfish (Cobb, 2007; DePaulo and Morris, 2006; Reynolds, 2008). Consequently, broken relationships are still portrayed as one of the nation's biggest social problems and the cause of almost all that is wrong in British society today. For example, a headline in the British centre-right broadsheet The Daily Telegraph reads 'Broken Britain needs lessons in love' (Knapton, 2009). This story was a summary of a report by the Children's Society entitled A Good Childhood: Searching for Values in a Competitive Age (2009) written by Lord Layard, a former advisor to Tony Blair. ${ }^{8}$ The report claimed that 'excessive individualism' had led to high rates of family break-up in Britain, with women's greater financial independence listed as one of the reasons for this increased individualism and consequent rising divorce rates. The Daily Telegraph summarizes the Layard report by stating that 'Britain has been damaged by rampant individualism... the selfish ethos needs to be replaced by a greater sense of personal responsibility and the common good' (Knapton, 2009: np). Separation, or a deliberate refusal to be coupled, becomes narrated as a selfish act that contributes to the breakdown of society.

The Daily Telegraph went onto claim that ' $\mathrm{t}]$ he country needs a radical shift towards an ethos of love' (Knapton, 2009: np). The implication here is that in an increasingly individualized society people have forgotten how to love properly, and that the values of love need to be learnt again. Yet it is the coupled two-parent family that is seen as crucial for teaching children these 'lessons in love'; somewhat paradoxically love is seen as both the problem and the answer. ${ }^{9}$ As Stychin (2006b: 29) notes, 'the family is cited for its central role in producing responsible, active new citizens, and as providing a counterbalance to rugged individualism and atomization'. Love is portrayed as providing a vital form of security and comfort in an increasingly individualized world (see Beck and Beck-Gernsheim, 1995 for further examples of how this narrative

\footnotetext{
${ }^{7}$ However, under the previous Conservative government this homosexual/heterosexual binary was not always quite so clear cut, as some forms of homosexuality were included into the imagined nation (the responsible private gay citizen) whilst some forms of heterosexuality were othered (the heterosexual single mother for example) (see Smith, 1994).

${ }^{8}$ Tony Blair was the Prime Minister for the majority of New Labour's time in government (1997-2007).

${ }^{9}$ See Ahmed (2003) for a similar discussion about how the notion of 'love thy neighbour' was taken up in government policy surrounding multiculturism after the 'race riots' in northern England in 2001. These riots were often reduced down to an issue a loveless nation, a personal failure to love 'the other', and thus profoundly individualized.
} 
works). This sort of rhetoric claims that the British nation has forgotten the moral codes that derive from long-term commitment, and that children need a stable two-parent family to learn the values of love. It is claimed that this so-called 'parenting deficit' has resulted in a 'moral deficit'. Britain is broken because it has forgotten how to love; and consequently the proposed solution to the nation's problems is to encourage people to love again and to make their relationships endure.

During the period of New Labour government there was hence a conscious attempt to teach the nation these 'lessons in love'. Longterm stable couples were seen as crucial for raising healthy children, and the key to building strong communities and a strong nation. As Barlow and Duncan (2000b: 140) note, New Labour were attempting to 'remould family structures and practices' in a way that would 'better promote social cohesion'. The government claimed that it had made a 'commitment to support couple relationships', and was looking at ways in which 'partners can be supported to sustain and strengthen their couple relationship at different life stages' (DCSF, 2010b: iii). Rather than seeing the personal sphere as something private, a number of government schemes explicitly attempted to shape and influence the nation's intimate lives. ${ }^{10}$ One example of this can be seen in 2008, when the government sponsored a national 'relationship summit'. Ed Balls, in his then role as Secretary of State for Children, Schools and Families, met with some of the nation's 'most famous' agony aunts from tabloid newspapers and magazines. The government claimed that it wished to support families via offering them relationship advice and helping to reduce conflict when relationships break down. After the summit Balls announced that $£ 6 \mathrm{~m}$ would be used on 'marriage and relationship support' through the Children, Young People and Families programme (HC, Hansard, 25/02/09: 807). In recognition of the additional strains placed on family relationships during the current so-called 'age of austerity', New Labour pledged an extra £3.1 million to voluntary organizations to enhance their services (DCSF, 2010a: 4.16). Yet when analysing New Labour family policy it becomes clear that there are some rather mixed messages communicated via their approach to relationship support. The government claimed that they want to use these charities to help support families going through separations, yet at the same time the rest of this policy document stressed the importance of couples staying together (DCSF, 2010a).

One of the other key ways in which the government has been attempting to teach people these 'lessons in love' is via the national school curriculum. In 2000 Sex and Relationships Education (SRE) was introduced to British schools in order to emphasize the importance of relationships and commitment, rather than just solely the practicalities of safer sex. This was the first time that British schools had a national framework to support lessons on intimate relationships and personal life. One government report claimed that this education was necessary as 'teenagers need specific advice about forming loving, stable relationships as adults' (DCSF, 2010b: 110). Another document from the Department of Education and Employment claims that SRE is 'about the understanding of the importance of marriage for family life, stable and loving relationships, respect, love and care' (DfEE, 2000: 5). Yet once again the government was careful not to imply that marriage is the only form of relationship that is valued, stating that:

[...] there are strong and mutually supportive relationships outside marriage. Therefore pupils should learn the significance of marriage and stable relationships as key building blocks of community and society. Care needs to be taken to ensure that there

\footnotetext{
10 This is of course not to claim that previous governments have not also intervened in personal life and intimate relationships. However, New Labour has perhaps been the most open about the intent of their policies.
}

is no stigmatisation of children based on their home circumstances (DfEE, 2000: 4).

However, it is questionable as to whether this sort of language cannot help but further stigmatize those who fall outside of these idealized notions of coupledom. Likewise, the predominant focus on the familial devalues the multitude of spaces where young people may feel loved and cared for, and continues to marginalize those who have not been brought up in supportive families. For example, in the 2010 Green Paper Support for All, the government claims that '[s]trong families give children love, identity, a personal history [...] They also help build understanding and mutual respect across generations' (DCSF, 2010a: 22). The effects of this sort of rhetoric on the self-esteem of those who were not brought up in these idealized loving families is never fully addressed in these policy documents.

Furthermore, it is important to note the ways in which both the funding for relationship charities and the new educational framework, are based on advice and support rather than control and sanctions, and thus sit contradictorily with some of New Labour's more punitive and disciplinary measures. ${ }^{11}$ These policies can be seen as in accordance with the precepts of neoliberal governance, encouraging self-governing reflexive subjects. 'Broken families' are reduced to a problem that can be fixed by counselling and better education; often the financial hardships that certain couples go through, and wider structural determinants of the couple form, are downplayed in these policies. For example, in a speech to the Relate Institute, New Labour's Health Secretary Alan Johnson (2007) claimed that poor parenting is the key cause of social exclusion, and low attainment, stating that '[p]arenting outstrips every other factor - including social class, ethnicity or disability - in its impact on [child] attainment'. ${ }^{12}$ Thus, this turn to education and counselling represents 'broken relationships' as primarily the result of individual problems, rather than broader socio-economic deprivation or state failures. ${ }^{13}$ Consequently, responsibility for 'broken Britain' has at times become profoundly individualized: the problems Britain faces will be solved by better parenting founded in stronger coupled relationships (Home Office, 2006). Relationship breakdown becomes a scapegoat on which to blame the nation's ills. Rhetoric about the couple as the foundation of the nation becomes a way for the state to bypass its own responsibilities, and downplay the economic and structural problems within the British nation. ${ }^{14}$

\section{The future of family policy under the Coalition government}

Under the current Coalition government Britain has seen an intensification of the idea that a key cause of 'Broken Britain' is the breakdown of families (Lister and Bennett, 2010). Prime Minister David Cameron has claimed that a whole host of problems are a direct result of the decline of the family and relationship breakdown, such as youth crime and anti-social behaviour. For example,

\footnotetext{
11 The image of a benevolent and supportive state masks a number of more punitive and disciplinary measures that were simultaneously taking place under New Labour, regarding tighter controls around eligibility for state benefits (Larkin, 2007).

12 Although New Labour were careful not to imply that a two-parent family was necessarily required for 'good' parenting, a number of their policy documents were very contradictory- containing claims about the dangers of stigmatizing lone parenthood, but at the same time citing evidence that a child's life chances were improved if brought up in a two parent family (see DCSF, 2008).

13 Though some policy documents do recognize that it is the financial hardship that follows relationship breakdown that is the key issue, rather than necessarily relationship breakdown itself (see DCSF, 2008).

14 There are other clear, and perhaps more explicit, examples of ways in which nation states use their 'progressive' position on LGBT rights to mask other inequalities (for example, see Puar's (2011) work on Israel's practices of 'pinkwashing', and the ways in which this is used to divert attention away from their occupation of Palestinian territories)
} 
the 'riots' that took place in some parts of England in 2011 were often depicted as a consequence of broken families and poor parenting (CSJ, 2011). Cameron (2011) blamed these acts on a lack of parental responsibility, in particular singling out 'children without fathers'. Making 'stronger families' founded upon 'stable relationships' was again invoked as a key strategy to mend 'broken Britain', with the Prime Minister claiming that '[i]f we want to have any hope of mending our broken society, family and parenting is where we've got to start' (see Harker and Martin, 2012). Families founded upon long-term committed couples were seen as central to the nation, not just in their role in biological reproduction, but also in reproducing appropriate moral codes (Kirby, 2009). This resulted in David Cameron (2011) proposing that he would introduce a 'family test' that would be applied to all domestic policy, claiming that '[i]f it hurts families, if it undermines commitment, if it tramples over the values that keeps people together... then we shouldn't do it'.

Those who do not, cannot, or will not form 'proper' long-lasting coupled relationships have thus been depicted in recent policy rhetoric as a key source of many of the nation's problems, and a threat to the nation itself (see CSJ, 2010 for a discussion about the 'problem' of broken relationships and the social good of married two-parent families). However, this emphasis on long-term coupledom did not really mark a shift in government policy, and the framework for this kind of rhetoric was partially set out under the New Labour government: indeed, when in opposition in the 1990s Tony Blair had campaigned for stronger communities drawing attention to housing estates where few children were being raised by their biological parents and where errant fathers were the norm (see Hubbard, 2000). It is therefore important to note that party lines seem increasingly blurred when it comes to family policy and although many might expect a return to 'traditional' (heterosexual) family values from the Conservative-led coalition, their current moves towards same-sex marriage seems to suggest otherwise. Current policy documents imply continuity rather than a break with New Labour family policy, as aspects of these policies seemingly cross party-political boundaries (Klett-Davies, 2012). ${ }^{15}$ However, when same-sex marriage is introduced in Britain we may in fact see a narrowing of the range of 'appropriate' intimacies, with a return to the promotion or marriage rather than the acceptance of a diverse range of family forms. It remains to be seen whether the Coalition government will use the legalization of same-sex marriage as an opportunity to push forward a narrow marriage-agenda that will further exclude those who are not part of a conjugal couple.

Yet, perhaps this bipartisan support for lesbian and gay rights becomes more explicable when we take into account the social and economic backdrop in which these changes have taken place. Wilson (2010) has argued that these progressive moves towards greater rights for lesbian and gay couples have often been won not solely on the grounds of liberal appeals to justice, inclusion and equality, but also as a consequence of the rising economic cost of care provision for the state. Wilson highlights that the recognition of same-sex partnerships has come at a time when many countries in Europe are facing a so-called 'care-crunch', with a rising number of people needing care but with fewer people to provide it. In effect, the state promotion of long-term coupledom supports and naturalizes the privatization of care within the family home. This implies that the inclusion of same-sex couples into the imagined British nation is not just about sexual equality, but rather there seem to be quite clear economic reasons for this shift in policy. The explicit economic incentives for the promotion of

\footnotetext{
15 However, there are a number profound contradictions within the Coalition's family policy, and their support of same-sex marriage sits uneasily with rhetoric about the problems of 'fatherless families' (Cameron, 2011).
}

coupledom can clearly be seen in a report on the Civil Partnership Act by the Department for Trade and Industry:

Strengthening adult couple relationships not only benefits the couples themselves, but also other relatives they support and care for, and, in particular, their children as they grow up and become the couples, parents and carers of tomorrow (DTI, 2004: 16, emphasis added).

If there is an explicit economic incentive for the government to promote long-term relationships, then conversely, living outside the couple-form can be understood as costly and potentially damaging to the nation. It is important to note that long-term coupledom is not just depicted as beneficial in terms of privatizing care in the home - the breakdown of coupled relationships is seen as an expensive burden on the state. A report by the independent think tank the Relationships Foundation claims that relationship breakdown costs the taxpayer an estimated $£ 37$ billion pounds annually. This figure has now been cited by the Coalition government, with some ministers inflating the figure even further; with Iain Duncan Smith (2010), the Secretary for State Work and Pensions, claiming that that relationship breakdown could cost society 'up to $£ 100$ billion'. These costs are calculated by looking at a number of areas, with one of the most significant being the supposed increase in claims to state benefits caused by divorce and relationship breakdown. The Relationships Foundation (2011: 8) claim that '60\% of women who divorce go onto social security benefits immediately' and that 'lone parents receive average tax credit and benefit payments five times larger than couples'. Here, separation and lone parenthood are framed as a costly economic problem, and it is argued that 'taxpayers pick up many of the costs when relationships breakdown' (Relationships Foundation, 2011: 4). In these portrayals there is no discussion about the need to provide more state support for women in low socio-economic positions who are left in a financially precarious position after their relationship come to an end, instead the answer to these problems is simply to encourage more couples to stay together. Hence, long-term coupledom is not just the foundation of the nation in terms of the reproduction of children, or the reproduction of moral values, couples are seen to play a key role in the reduction of state benefits. As Anderson (1991) notes, elites in society have always had most influence over the narratives we tell about the nation, and consequently these seeming moves toward greater sexual equality need to be understood as also serving the interest of those in power. The state promotion of coupledom comes at a time when Britain is witnessing a significant reduction of public sector spending on welfare benefits. ${ }^{16}$ The British nation might therefore be regarded as economically dependent upon the continuation of the couple form; coupledom provides the economic base to the nation and helps further the retrenchment of certain sections of the welfare state.

\section{Conclusion}

This article examined how New Labour attempted to respond to the so-called 'crisis' in intimate life (fewer marriages, more cohabiting couples, and more single-headed households) through attempts to promote the importance of long-term committed coupled relationships. I highlighted the ways in which family policy under New Labour saw a shift from promoting 'the family' to

\footnotetext{
16 Although New Labour increased their spending on certain aspects of the welfare state, there was still a neoliberal agenda that sought to shift responsibility from the state to the private sector and to the individual (Barker and Lamble, 2009). New Labour's policy on welfare reform was clearly underpinned by a desire for 'economic efficiency' (Barlow and Duncan (2000a): 27), and cutting back on certain forms of 'bad welfare' (benefits) in order to reallocate resources to 'good welfare' (health and education) (Powell, 2000).
} 
'families' via the 2004 Civil Partnership Act. Nevertheless, despite successive government attempts to recognize a diverse range of family formations, I argued that family policy still presented a rather narrow understanding of what intimate life could be. Instead of speaking of the married heterosexual couple, government policy began to talk about the importance of long-term committed couples, regardless of sexual orientation. There was a move away from the assumption that the nation is founded upon the heterosexual bond to the idea that '[s]trong and healthy relationships are [...] paramount regardless of the structure' (DCSF, 2008: 8). Thus despite the supposed recognition of diverse family forms, long-term coupled relationships were still depicted as essential to the wider community, society and the nation. As a result, those who were not part of a couple were depicted as failures; and not just personal failures, but a failure to the nation as a whole. Despite the New Labour government claiming that it was offering 'support for all', it is clear that certain forms of intimate attachment were promoted as more important than others. Moreover, what was lacking in these governmental debates was any consideration of what makes these changes and shifts in family formation both possible and even desirable for many people. The idea that long-term coupledom might be dysfunctional is never considered, and there is no critical questioning of why these changes in family formation have come about, or that it might be dangerous to continue to encourage people to enter into, or remain within, privatized isolated coupled relationships. As Smith (1994: 89) notes, the 'phantasmatic construction of the family as the antagonism-free centre of the British nation' stands at odds with the lived reality of family life given the family home, far from being a haven and retreat, can so often be a space of exclusion, control, violence and abuse (see also Warrington, 2001). Under New Labour coupledom was seen as the solution to the nation's problems rather than a potential problem in itself. The government failed to recognize the systemic structural inequalities that are built into the marriage contract and the economic dependencies it creates.

In this article I outlined the importance of thinking critically about how coupledom is naturalized and privileged whilst the non-coupled are excluded and stigmatized. ${ }^{17}$ The non-coupled continue to fall outside of the remit of mononormative notions of citizenship (Bell and Binnie, 2000; Hubbard, 2001), and thus remain excluded from these 'new equalities landscapes'. Consequently, framing debates about rights and equality solely around notions of sexual citizenship does little to help challenge the normative ways in which sexual-romantic love forms the basis of citizenship (Cobb, 2007). The state promotion of coupledom excludes not just those whose sexual encounters are far from romantic, but also those for whom sex and romance may not be the key intimate attachment in their lives. Thus dominant notions of sexual citizenship continue to exclude those who might be single, asexual, or those who see friendship, or other forms of kinship as their most important intimate connections (Budgeon, 2008; Carrigan, 2011; Roseneil, 2004). In order to denaturalize the mononormative nation it is important to challenge the idea that coupledom should be the marker of citizenship. Therefore, although this article has focused solely on the UK, I hope this research may speak across geographic boundaries, in order to think about how mononormativity plays out in other nation-states. Comparative work may enable us to think further about whether the increased acceptance of lesbian and gay partnerships necessarily comes hand in hand with the increased privileging of the sexual-romantic couple form.

\footnotetext{
17 Of course this coupled/non-coupled binary needs further consideration, and the classed dimensions to these distinctions should not be overlooked, as there is clearly a different narrative at work when speaking about the single-mother who receives state welfare, in comparison to the portrayal of the single middle-class career woman.
}

Geographers have only just begun to explicitly address the ways in which space serves to normalize coupledom (Johnston and Longhurst, 2010; Oswin, 2010; Ramdas, 2012), and the concept of mononormativity has yet to be fully explored. In this respect it is worth remembering that government policy and education represents just one domain where mononormativity is reproduced. Attention also needs to be given to the more mundane and everyday spaces in which mononormativity is both enforced and challenged, including diverse spaces of work, rest and play. Documenting where coupledom is produced, regulated and normalized is one important route to identifying where it can be resisted, allowing geographers to play an important role in challenging the inequalities that persist at the heart of the nation-state.

\section{References}

Adeniji, A., 2001. In: Bertilsdotter, H. (Ed.), Ordningsstörande begär: Biteori som kritik av antropologisk sexualitetsforskning, 5. Lambda Nordica, pp. 1-2.

Ahmed, S., 2003. In the name of love. Borderlands: e-Journal 2 (3).

Anderson, B., 1991. Imagined Communities: Reflections on the Origin and Spread of Nationalism. Verso, London.

Barker, M., Langdridge, D., 2010. Whatever happened to non-monogamies? Critical reflections on recent research and theory. Sexualities 13 (6), 748-772.

Barker, N., Lamble, S., 2009. From social security to individual responsibility: sanctions, conditionality, and punitiveness in the welfare reform Bill 2009 (Part One). Journal of Social Welfare and Family Law 31 (3), 321-332.

Barlow, A., Duncan, S., 2000a. Supporting families? New labour's communitarianism and the 'Rationality Mistake' Part I. Journal of Social Welfare and Family Law 22 (1), 23-42.

Barlow, A., Duncan, S., 2000b. Supporting families? New labour's communitarianism and the 'Rationality Mistake' Part II. Journal of Social Welfare and Family Law 22 (2), 129-143.

Beck, U., Beck-Gernsheim, E., 1995. The Normal Chaos of Love. Polity Press, Cambridge.

Bell, D., Binnie, J., 2000. The Sexual Citizen: Queer Politics and Beyond. Polity Press, Cambridge.

Bell, D., Binnie, J., 2006. Geographies of sexual citizenship. Political Geography 25, 869-873.

Berlant, L., Warner, M., 1998. Sex in public. Critical Inquiry 24, 547-566.

Budgeon, S., 2008. Couple culture and the production of singleness. Sexualities 11 (3), 301-316.

Browne, K., 2011. By partner we mean ...: alternative geographies of 'gay marriage'. Sexualities 14 (1), 100-122.

Carrigan, M., 2011. There's more to life than sex? Difference and commonality within the asexual community. Sexualities 14 (4), 462-478.

Cameron, D., 2011. Speech on Troubled Families, Sandwell Christian Centre, Oldbury. <http://www.newstatesman.com/uk-politics/2011/12/ troubledfamilies-family> (15.12.11).

Cobb, M., 2006. God Hates Fags: The Rhetorics of Religious Violence. New York University Press, New York.

Cobb, M., 2007. lonely. South Atlantic Quarterly 106 (3), 445-457.

Cooper, D., Herman, D., 1991. Getting the family right: legislating heterosexuality in Britain, 1986-1991. Canadian Journal of Family Law 10, 41-63.

Centre for Social Justice, 2010. Green Paper on the Family. Centre for Social Justice, London.

Centre for Social Justice, 2011. Strengthening the Family and Tackling Family Breakdown. Centre for Social Justice, London.

Denzin, N.K., Lincoln, Y.S., 1998. The Landscape of Qualitative Research. Sage, London.

Department for Children Schools and Families., 2008. Families in Britain Evidence Paper. HMSO, London.

Department for Children Schools and Families, 2010a. Support for All: The Families and Relationships Green Paper. HMSO, London.

Department for Children Schools and Families, 2010b. Relationships Matter: Understanding the Needs of Adults Regarding Relationship Support, Research Report DCSF 2010- RR233. Institute of Health and Society, Newcastle.

Department for Education and Employment, 2000. Sex and Relationship Education Guidance. HMSO, London.

Department of Trade and Industry, 2004. Final Regulatory Impact Assessment: Civil Partnerships. <http://www.hmrc.gov.uk/ria/full_civil-partnership.pdf>.

DePaulo, B.M., Morris, W.L.M., 2006. The unrecognized stereotyping and discrimination against singles. Current Directions in Psychological Science 15 (5), 251-254.

Duggan, L., 2002. The new homonormativity: the sexual politics of neo-liberalism. In: Castronovo, R., Nelson, D.D. (Eds.), Materializing Democracy. Duke University Press, Durham.

Duncan, S., Smith, D., 2003. Geographies of family formations: spatial differences and gender cultures in Britain. Transactions of the Institute of British Geographers 27, 471-493.

Edwards, R., Duncan, S., 1997. Supporting the family: lone mothers, paid work and the underclass debate. Critical Social Policy 17 (4), 29-49. 
Fairclough, N., 2000. New labour: new language? Routledge, London.

Harker, C., Martin, L., 2012. Familial relations: spaces, subjects and politics. Environment and Planning A 44 (4), 768-775.

Home Office, 1998. Supporting families: a consultation document. HMSO, London. Home Office, 1999. Supporting Families: Summary of Responses. HMSO, London. Home Office, 2006. Respect Action Plan. Respect Task Force. HMSO, London.

Hubbard, P., 2000. Desire/disgust: mapping the moral contours of heterosexuality. Progress in Human Geography 24, 191-203.

Hubbard, P., 2001. Sex zones: intimacy, citizenship and public space. Sexualities 4, 51-68.

Hubbard, P., this issue. Kissing is not a universal right: sexuality, law and the scales of citizenship. Geoforum. http://dx.doi.org/10.1016/j.geoforum.2012.08.002

Jakobsen, J., 2002. Can Homosexuals End Western Civilization as We know it? Family Values in a Global Economy. In: Cruz-Malave, A., Manalansan, M. (Eds.), Queer Globalization / Local Homosexualities. New York University Press, New York.

Johnson, A., 2007. Strong Families, Strong Society, Inaugural Lecture to the Relate Institute, February 2007, London. .

Johnston, L., Longhurst, R., 2010. Space, Place, and Sex: Geographies of Sexualities. Rowman \& Littlefield, New York.

Kirby, J., 2009. From broken families to the broken society. The Political Quarterly 80 (2), 243-247.

Klett-Davies, M., 2012. A review of social trends and family and relationships policies in England and Wales (1997-2011). Families, Relationships, Societies 1 (1).

Knapton, S., 2009. Broken Britain Needs Lessons in Love. The Telegraph 02/02/09. $<$ http://www.telegraph.co.uk/family/4425528/Broken-Britain-needs-lessonsin-love.html>.

Larkin, P.M., 2007. The 'Criminalization' of social security law: towards a punitive welfare state? Journal of Law and Society 34 (3), 295-320.

Layard, R., 2009. A Good Childhood: Searching for Values in a Competitive Age. Penguin, London.

Lord Chancellor's Department, 2002. Moving Forward Together: A Proposed Strategy for Marriage and Relationship Support for 2002 and Beyond. HMSO, London.

Lister, R., 2001. New Labour: a study in ambiguity from a position of ambivalence. Critical Social Policy 21 (4), 425-447.

Lister, R., Bennett, F., 2010. The new 'champion of progressive ideals'? Cameron's Conservative Party: poverty, family policy and welfare reform. Renewal: A Journal of Social Democracy 18 (1-2), 84-109.

Massey, D., 2004. Geographies of responsibility. Geografiska Annaler: Series B, Human Geography 86, 5-18.

Mayer, T. (Ed.), 2000. Gendered Ironies of Nationalism: Sexing the Nation. Routledge, London and New York.

McDermott, E., 2011. The world some have won: sexuality, class and inequality. Sexualities 14 (1), 63-78.

Nast, H., 1998. Unsexy geographies. Gender place \& Culture: A Journal of Feminist Geography 5 (2), 191-206.

Oswin, N., 2010. The modern model family at home in singapore: a queer geography. Transactions of the Institute of British Geographers 35, 256-268.

Peel, E., Harding, R., 2008. Recognizing and celebrating same-sex relationships: beyond the normative debate. Sexualities 11 (6), 659-666.

Phillips, R., 2009. Settler colonialism and the nuclear family. Canadian Geographer 53 (2), 239-253.

Pieper, M., Bauer, R., 2005. Call for Papers: International Conference on Polyamory and Mono-Normativity. Research Centre for Feminist, Gender \& Queer Studies, University of Hamburg, November, 5th 2005
Plummer, K., 2001. The square of intimate citizenship: some preliminary proposals Citizenship Studies 5, 237-253.

Plummer, K., 2003. Intimate Citizenship: Private Decisions and Public Dialogues University of Washington Press, Seattle.

Powell, M., 2000. New Labour and the third way in the British welfare state: a new and distinctive approach? Critical Social Policy 20 (1), 39-60.

Puar, J., 2011. Citation and censorship: the politics of talking about the sexua politics of Israel. Feminist Legal Studies 19 (2), 133-142.

Ramdas, K., 2012. Women in Waiting? Singlehood, marriage, and family in Singapore. Environment and Planning A 44 (4), 832-848.

Relationships Foundation, 2011. When Relationships Go Wrong: Counting the Cost of Family Failure. <http://www.relationshipsfoundation.org>.

Reynolds, J., 2008. The single woman: a discursive investigation. Taylor \& Francis, London.

Rich, A., 1980. Compulsory heterosexuality and lesbian existence. Signs 5, 631-660. Richardson, D., 2000. Rethinking sexuality. Sage, London.

Richardson, E.H., Turner, B.S., 2001. Sexual, intimate or reproductive citizenship? Citizenship Studies 5 (3), 329-338.

Roseneil, S., 2004. Why we should Care about Friends: An Argument for Queering the Care Imaginary in Social Policy. Social Policy and Society 3, 409-419.

Roseneil, S., 2010. Intimate citizenship: a pragmatic, yet radical, proposal for a politics of personal life. European Journal of Women's Studies 17 (1) 77-82.

Roseneil, S., Budgeon, S., 2004. Cultures of intimacy and care beyond the family: personal life and social change in the early twenty-first century. Current Sociology 52 (2), 135-159.

Rubin, G., 1984. Thinking sex: notes for a radical theory of the politics of sexuality. In: Rubin, G., Vance, C. (Eds.), Pleasure and Danger: Exploring Female Sexuality. Pandora Press, London.

Smart, C., 2007. Same sex couples and marriage: negotiating relational landscapes with families and friends. Sociological Review 55, 671-686.

Smith, A.M., 1994. New Right Discourse on Race and Sexuality: Britain, 1968-1990. Cambridge University Press, Cambridge.

Smith, A.M., 2007. Welfare Reform and Sexual Regulation. Cambridge University Press, Cambridge.

Smith, I.D., 2010. Relate Annual Conference. <http://www.dwp.gov.uk/newsroom/ ministers-speeches/2010/03-11-10.shtml> (03.11.10)

Stychin, C.F., 2006a. 'Las Vegas is Not Where we Are': Queer Readings of the Civil Partnership Act. Political Geography 25, 899-920.

Stychin, C.F., 2006b. Family Friendly? Rights, Responsibilities and Relationship Recognition. In: Diduck, A., O'Donavan, K. (Eds.), Feminist Perspectives on Family Law. Routledge, London and New York.

Taylor, Y., 2011. Sexualities and class. Sexualities 14 (1), 3-11.

Warrington, M., 2001. 'I must get out': the geographies of domestic violence. Transactions of the Institute of British Geographers 26 (3), 365-382.

Weeks, J., 2007. The World We Have Won: The Remaking of Erotic and Intimate Life Routledge, London.

Weeks, J., Heaphy, B., Donovan, C., 2001. Same Sex Intimacies: Families of Choice and Other Life Experiments. Routledge, London and New York.

Wilkinson, E., 2012. The romantic imaginary: compulsory coupledom and single existence. In: Hines, S., Taylor, Y. (Eds.), Sexualities: Reflections and Futures. Palgrave MacMillan, Basingstoke.

Wilson, A.R., 2010. Feminism and same-sex marriage: who cares? Politics and Gender 6, 134-145.

Women and Equality Unit, 2003. Responses to Civil Partnership: A Framework for the Legal Recognition of Same-Sex Couples. 